EESTI NSV TEADUSTE AKADEEMIA TOIMETISED 1955. IV kd., nr. 3 ИЗВЕСТИЯ АКАДЕМИИ НАУК ЭСТОНСКОИ ССР 1955. ТоМ IV, № 3

\title{
ЗАВИСИМОСТЬ ЭКОНОМИЧЕСКИХ ПОКАЗАТЕЛЕЙ ДОБЫЧИ СЛАНЦА ОТ СТЕПЕНИ ПОРОДООТБОРКИ В ЗАБОЕ И НА ПОВЕРХНОСТИ
}

\author{
Д. Т. КУЗНЕЦОВ, \\ кандидат экономических наук
}

И. 3. КАГАНОВИЧ

х. Р. мииль

За период с 1946 по 1954 год добыча сланца в Эстонской ССР выросла более чем в 3 раза.

Вместе с тем рост потребности народного хозяйства в сланце и продуктах его переработки выдвигает перед сланцевой промышленностью задачу еще более быстрыми темпами увеличивать добычу сланца при максимальной экономии труда и средств производства. При этом качество добываемого сланца должно удовлетворять повышенным требованиям, предъявляемым сланцеперерабатывающей промышленностью.

Однако темпы роста производительности труда тормозятся применяемым в настоящее время способом повышения качества сланца. Требования к отсортировке пустой породы в забое все время повышаются: допустимое содержание видимой породы ${ }^{1}$ в рядовом сланце составляло 10 процентов, затем снизилось до 8 и, наконец, до 6 процентов. В результате навалоотбойщики больше половины рабочего времени затрачивают на отсортировку породы.

Повышение требований к породоотборке в забое приводит также к увеличению эксплуатационных потерь отбитого сланца. Все это затрудняет борьбу за снижение себестоимости добычи сланца.

Задача повышения качества сланца нуждается в ином решении. Оно должно одновременно содействовать как росту добычи сланца без дополнительных капитальных вложений (за счет снижения потерь), так и увеличению производительности труда шахтеров, снижению себестоимости сланца.

Способом решения этой проблемы, подсказываемым практикой, является обогащение рядового сланца на поверхности.

1 Понятие «видимая порода» не имеет вполне определенного содержания. Оно не определяет фактического содержания породы в добываемом сланце. В существующих условиях на шахте «Кивиыли» куски породы размером менее 25 мм не считаются видимой породой и входят в чистую добычу. Видимой породой считаются только куски породы размером более 25 мм. То же и со сростками. Если они содержат в себе сланца более 50 процентов, то их относят к сланцу, а если менее 50 процентов к видимой породе. 
Исследование вопроса об экономичности добычи сланца с бо́льшим или меньшим содержанием органического вещества проведено бригадой Института экономики Академии наук Эстонской ССР в творческом содружестве с инженерно-техническими работниками комбината «Кивиыли» Министерства местной и сланце-химической промышленности ЭССР на шахте комбината в 1954 году. Опытные работы показали полную возможность и экономичность добычи сланца с минимальной в условиях шахты «Кивиыли» породоотборкой в лаве и последующим обогащением на поверхности.

В работе учтены исследования, проведенные в предшествующий период.

В 1946-1947 годах анализом роста производительности труда забойщика и снижения себестоимости добычи с уменьшением содержания пустой породы в добываемом сланце занимался научный сотрудник Института химии Академии наук ЭССР И. А. Уск. Целью своей работы он ставил экономическое обоснование возможности добывания на шахтах высококачественного сланца, необходимого сланцеперерабатывающим предприятиям.

Путем опытных работ на шахте «Кохтла» в условиях камерно-столбовой системы разработок была установлена зависимость производительности труда забойщика от содержания пустой породы в сланще.

Работа- И. А. Уска, однако, не дала полного ответа на вопросы о влиянии степени обогащения на эксплуатационные потери сланца и на его себестоимость.

Новым шагом в этом направлении яввилась работа научного сотрудника Института химии Академии наук ЭССР А. С. Фоминой, дающая развернутую характеристику качества сланца отдельных пластов и промпачек шахт Министерства местной и сланце-химической промышленности ЭССР.

В 1952-1953 годах под руководством доцента Московского института химического машиностроения В. В. Шелоумова выполнена работа, позволившая сделать предварительный вывод о том, что «наиболее выгодным является добыча необогащенного сланца, затем обогащение его на поверхности и переработка уже обогащенного сланца».

Анализ производился В. В. Шелоумовым и сотрудниками по двум вариантам: добыча необогащенного сланца со средним содержанием органического вещества 26,8 процента и обычного сланца со средним содержанием органического вещества 30,2 процента ${ }^{2}$.

Во время опытов не удалось осуществить контроль за качеством добываемого необогащенного сланца. Содержание органической массы в необогащенном сланце определялось условно, расчетным путем.

Указанное исследование позволило установить, что при добыче сланца в условиях минимальной породоотборки в забое значительно повышается съем сланца с 1 м $^{2}$ площади выемки (на 29,5 процента, в пересчете на органическое вещество). Значительно повысилась также производительность труда навалоотбойщиков и забойщиков.

Однако данные этой работы не дают точной картины изменения производительности труда, поскольку фактически расход рабочего времени навалоотбойщиков и забойщиков внутри смены не учитывался. Не была также получена экономически обоснованная величина себестоимости бедного сланца. Обогащение бедного сланца на поверхности в ходе исследования не осуществлялось. Между тем экономические показатели переработки сланца изменяются с улучшением его качества. Поэтому в

2 В обоих вариантах имеется в виду среднее содержание органического вещества в технологическом сланце. 
работе делается вывод, что с переходом на добычу и переработку бедного сланца «заметного экономического эффекта не получилось».

Настоящее исследование можно рассматривать как продолжение упомянутых выше и ряда других работ. Экономическая эффективность добычи сланца анализируется по трем вариантам опытных работ.

1. Добыча бедного сланца с содержанием 30,4 процента органического вещества (в забое отсортировывались куски породы размером более 75 мм и сростки, содержащие более 75 процентов породы).

2. Добыча обычного сланца с содержанием 33,1 процента органического вещества (в забое отсортировывались куски породы размером более 25 мм и сростки, содержащие более 50 процентов породы).

3. Добыча богатого сланца с содержанием 37,6 процента органического вещества (в забое отсортировывались куски породы размером более 25 мм и сростки, содержащие более 25 процентов породы).

Все данные проведенного нами исследования относятся к условиям системы разработок лавами.

\section{Зависимость производительности труда шахтеров от содержания органического вещества в добываемом сланце}

Уровень производительности труда навалоотбойщиков при различных вариантах опытных работ свидетельствует о том, что трудоемкость добычи тонны рядового сланца находится в прямой зависимости от условий породоотборки в забое.

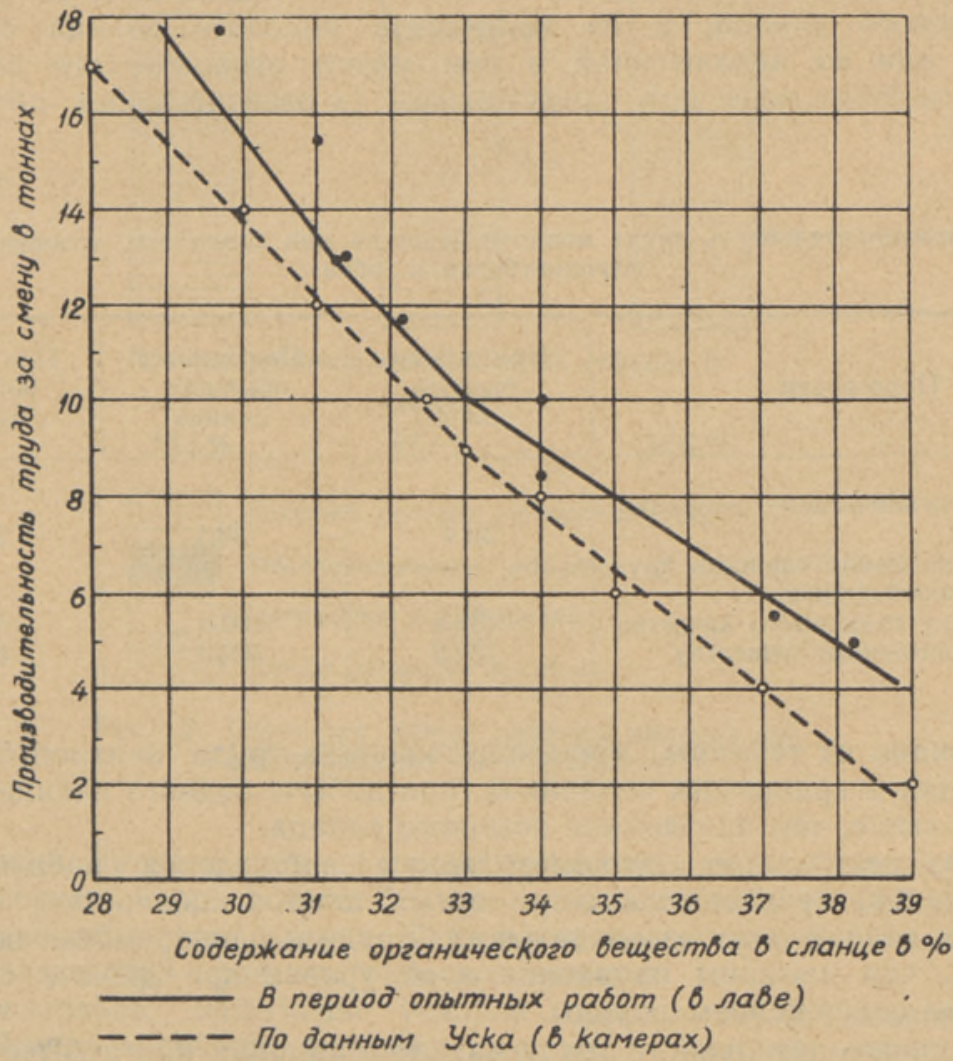

Рнс. I. Производительность труда навалоотбойшика в зависимости от степени обогашения сланща в забое. 
При добыче бедного сланца производительность труда навалоотбойщика по рядовому сланцу на 43,5 процента выше, а при добыче богатого сланца на 46,5 процента ниже, чем при обычных условиях породоотборки в лаве.

Указанная закономерность проявляется не только в средних данных по вариантам опытных работ, но и в цифрах производительности труда за каждый день испытаний. Как показывает рис. 1, эта зависимость между производительностью труда навалоотбойщиков и содержанием органического вещества в сланце проявляется почти одинаковым образом как в данных настоящего исследования, так и в результатах, полученных И. А. Уском в иное время и в иных условиях.

Вместе с тем необходимо учесть, что с переходом от одного варианта добычи сланца к другому навалоотбойщики не могли полностью в короткий срок освоить приемы работы, что сказалось на уровне производительности их труда.

Если принять в расчет не средний показатель достигнутого уровня производительности труда при добыче бедного сланца, а показатели тех дней, когда производительность труда навалоотбойщиков была выше средней, то объем продукции навалоотбойщика в смену составит 16 т рядового сланца. Рост производительности труда при добыче бедного сланца по сравнению с добычей обычного сланца составляет 60 процентов.

Сланец, добываемый при различных условиях породоотборки в забое, имеет, естественно, разное качество. Поэтому для достижения сравнимости уровня производительности труда при всех вариантах опытных работ следует ее рассчитать исходя не из общего объема добываемого рядового сланца, а из количества рядового сланца обычного качества или из заключенной в нем массы органического вещества. Результаты этого пересчета представлены (в относительных цифрах) в таблице 1.

Таблица 1

\section{Производительность труда навалоотбойщика при различных условиях породоотборки в забое}

\begin{tabular}{l|c|c|c}
\hline \multicolumn{1}{c|}{ Показатели } & $\begin{array}{c}\text { При добыче } \\
\text { бедного } \\
\text { сланпа }\end{array}$ & $\begin{array}{c}\text { При добыче } \\
\text { обычного } \\
\text { сланца }\end{array}$ & $\begin{array}{c}\text { При добыче } \\
\text { богатого } \\
\text { сланца }\end{array}$ \\
\hline $\begin{array}{l}\text { Процент органического вещества } \\
\text { В сланце }\end{array}$ & 30,4 & 33,1 & 37,6 \\
$\begin{array}{l}\text { Сменная производительность тру- } \\
\text { да навалоотбойика, \% }\end{array}$ & 132,5 & 100,0 & 58,5 \\
а) по сланцу сравнимого качества & 132,0 & 100,0 & 63,4 \\
б) по органическому веществу & & &
\end{tabular}

Как видно из таблицы, производительность труда навалоотбойщика, выраженная в сравнимых величинах, при добыче бедного сланца на 32,5 процента выше, чем при добыче обычного сланца.

Анализ результатов хронометражного наблюдения работы навалоотбойщиков, произведенного во время опытов, полностью подтверждает эти данные о производительности труда и одновременно позволяет выяснить, чем вызваны изменения в ее уровне при добыче сланца с различным содержанием породы.

Рост производительности труда навалоотбойщика при добыче бедного сланца происходит за счет изменения в структуре рабочего времени: значительно сокращается время, затрачиваемое на породоотборку и 
выкладку бутовых полос, и возрастает затрата рабочего времени на навалку сланца (рис. 2).

Хронометраж показал, что при добыче бедного сланца навалоотбойщик затрачивает на породоотборку и выкладку бутовых полос 42,1 процента рабочего времени против 53,5 процента при добыче обычного сланца. Добыча богатого сланца требует на эти операции 65,2 процента рабо-

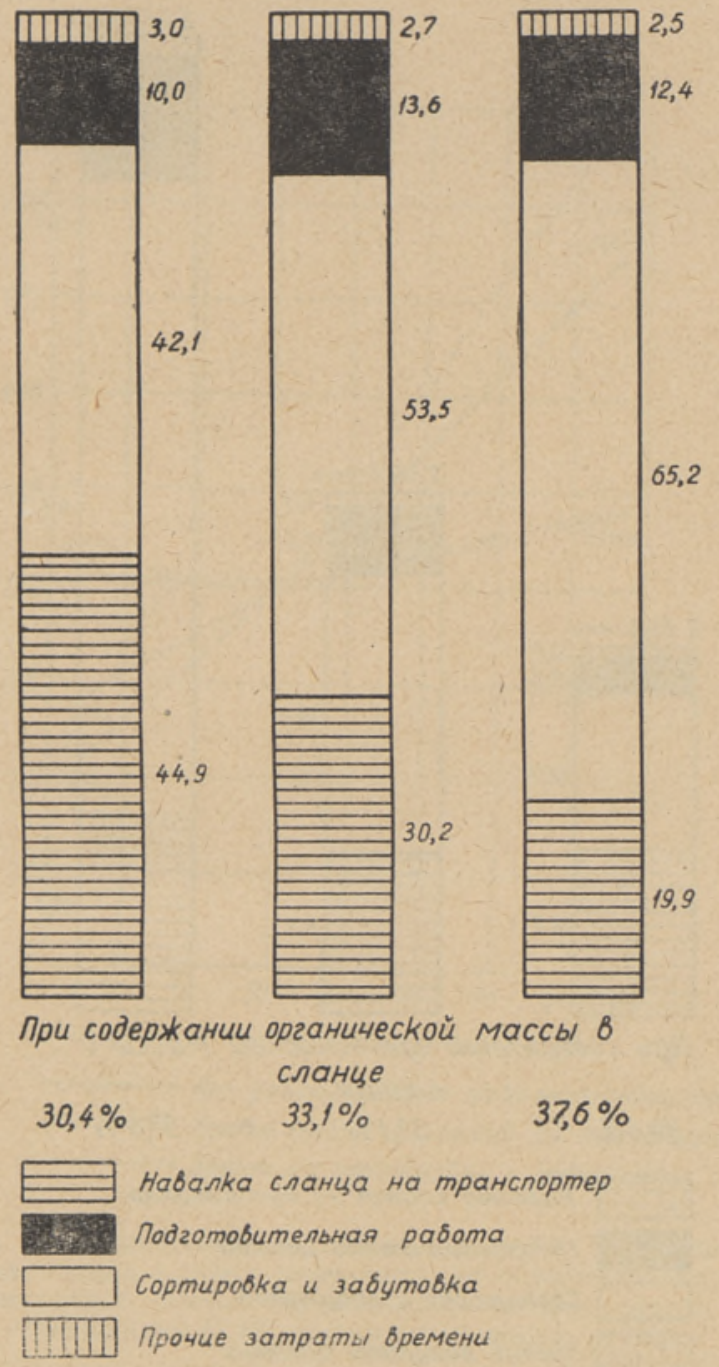

Рис. 2. Структура затрат рабочего времени навалоотбойщика (без простоев).

чего времени. Затрата времени на основную операцию - навалку сланца на транспортер - при добыче бедного сланца составляет 44,9 процента, при добыче обычного сланца 30,2 процента и при добыче богатого сланца только 19,9 процента рабочего времени.

Следовательно, облегчение условий породоотборки позволяет навалоотбойщику в течение рабочего дня затрачивать на производительную операцию навалки сланца почти в полтора раза больше времени, чем при добыче сланца обычного качества. 
При переходе на добычу бедного сланца рост производительности труда навалоотбойщика, по данным хронометража, примерно равен производительности труда, определенной по данным непосредственного учета объема продукции. Незначительное различие при этом объясняется тем, что рост производительности труда по данным учета объема продукции отражает среднюю выработку всех навалоотбойщиков в лаве,

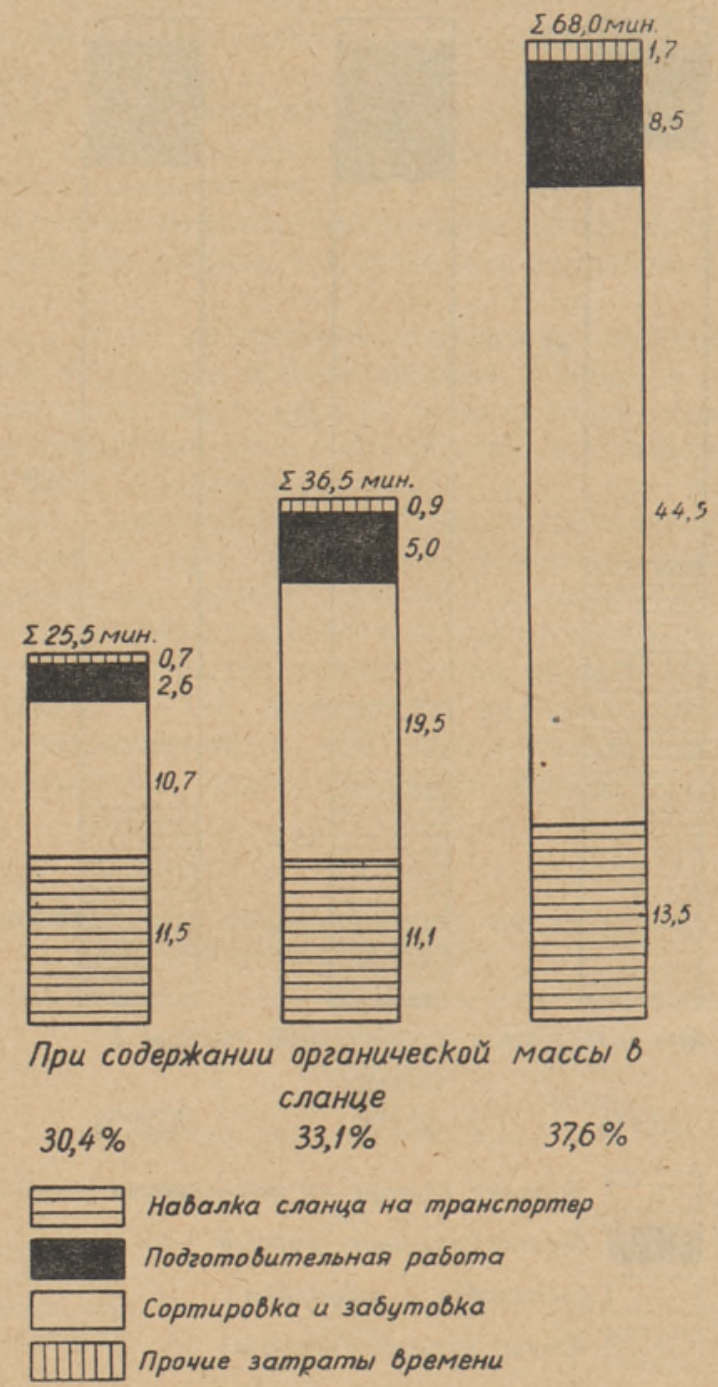

Рис. 3. Трудоемкость процесса навалоотбойки одной тонны сланца в лаве (в минутах).

а данные хронометража являются средними по выработке двух навалоотбойщиков, за которыми велось наблюдение.

В зависимости от степени породоотборки в забое изменяется трудоемкость добычи тонны сланца (рис. 3 и 4). На добычу тонны обычного сланца навалоотбойщик затрачивает в среднем 36,5 мин., на добычу бедного сланца - 25,5 мин. и на добычу богатого сланца - 68 мин. Снижение трудоемкости добычи тонны бедного сланца при минимальной отборке породы в забое вызвано главным образом сокращением времени, затра- 
чиваемого на породоотборку и выкладку бутовых полос. На эти операции при добыче тонны бедного сланца требуется почти вдвое меньше времени, чем при добыче обычного сланца (10,7 мин. против 19,5 мин). При добыче тонны богатого сланца на эти операции затрачивается 44,3 мин. Трудоемкость остальных операций, в первую очередь навалки сланца на транспортер, при добыче бедного, обычного и богатого сланца остается почти неизменной.

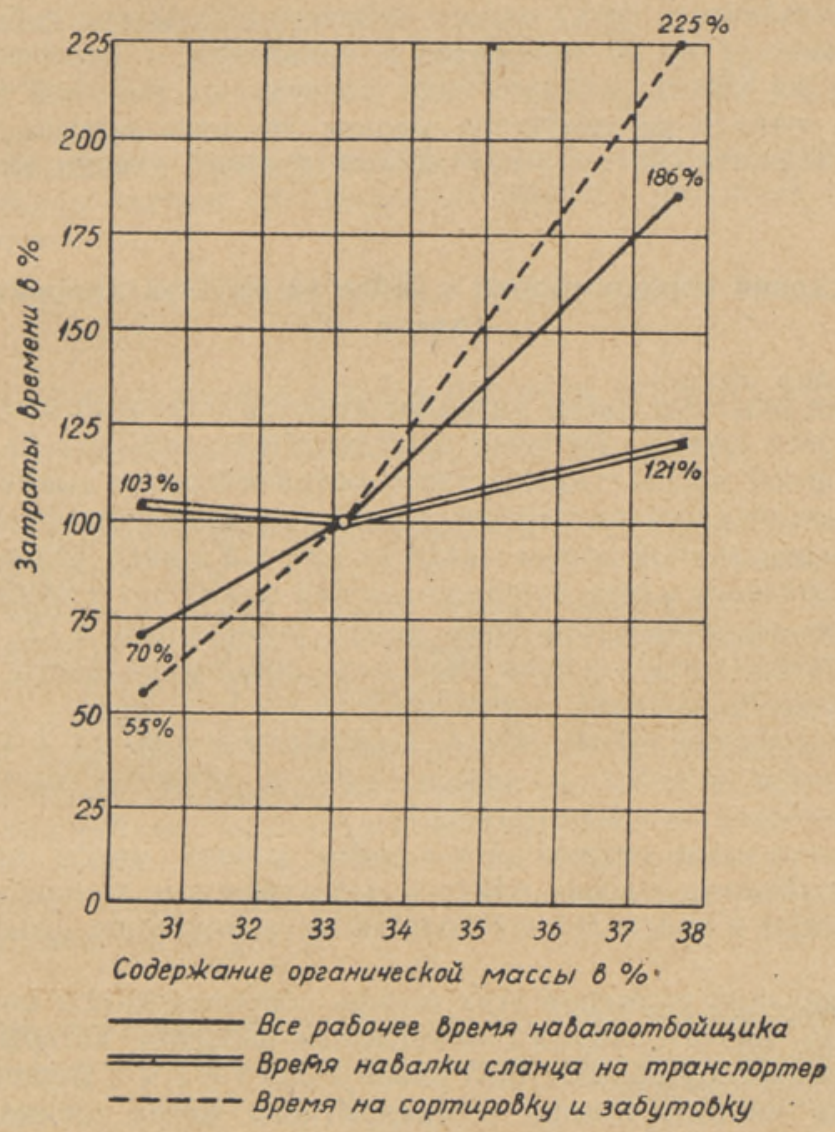

Рис. 4. Трудоемкость основных операций по добыче тонны сланца в лаве в зависимости от содержания в нем органической массы (трудоемкость добычи сланца с содержанием $33,1 \%$ органической массы $=100$ ).

Смягчение требований к породоотборке в забое имеет следствием не только увеличение производительности, но и облегчение труда навалоотбойщиков, так как сокращаются затраты труда на породоотборку, значительно уменьшается рабочее напряжение и концентрация внимания, что в существующих условиях вызвано необходимостью отсортировки очень мелких кусков породы.

Так как навалоотбойщики составляют основную категорию шахтеров, то рост производительности их труда обусловливает повышение производительности труда рабочих по шахте в целом. Последнее, помимо того, связано и с уменьшением потерь сланца. С другой стороны, при добыче бедного сланца несколько снижается полезная производительность труда 
транспортных рабочих за счѐт перевозки вместе со сланцем дополнительного количества породы.

Характер изменения производительности труда рабочих по всей шахте в целом раскрывается в данных о трудоемкости добычи 100000 т бедного и обычного сланца (с учетом рабочих всех профессий).

Трудоемкость добычи 100000 т сланца уменьшается при добыче бедного сланца на 14,5 процента. При этом число рабочих, потребное для добычи этого количества сланца, уменьшается с 613 до 524 человек.

Производительность труда одного рабочего шахты при добыче бедного сланца повышается на 20 процентов в сравнении с добычей обычного сланца. Если же учесть рабочую силу, занятую на шахтной поверхности обогащением сланца до обычного уровня, то рост производительности труда по всей шахте составит при добыче бедного сланца 17 процентов.

\section{Влияние условий породоотборки в забое на эксплуатационные потери сланца}

На участке опытных работ разрабатываются сланценосные слои В, С, $\mathrm{D}, \mathrm{E}$ и две трети слоя F. Рабочая производительность пласта составляет 4,11 тонны горной массы с квадратного метра площади выемки.

В забое горная масса подвергается разборке. После отсортировки породы бо́льшая часть горной массы выдается на-гора в виде рядового сланца. С одного квадратного метра площади выемки при существующих условиях породоотборки во время опытных работ добывалось 2,12 т рядового сланца. За первые пять месяцев 1954 года добыча рядового сланца на опытном участке была равна в среднем $2,11 \mathrm{~T} / \mathrm{m}^{2}$.

Остальная отбитая горная масса, в количестве 1,99 т с 1 м $^{2}$ площади выемки, остается в забое и используется в качестве материала для закладки выработанного пространства.

Значительная часть остающейся в забое горной массы представляет собой породу (белая, розовая плита и известняковые конкреции). Кроме того, сюда входит и определенная доля эксплуатационных потерь отбитого сланца.

Для определения размеров этих потерь сопоставляются цифры фактического выхода чистого сланца с возможным выходом, который, согласно данным геологической съемки, был равен 2,033 т с 1 м $^{2}$. Величина фактического съема чистого сланца с квадратного метра площади выемки может быть получена, если из объема выхода горной массы вычесть все количество содержащейся в ней породы.

Нужно, однако, иметь в виду, что эта задача отнюдь не решается установлением процента видимой породы в рядовом сланце. Помимо видимой породы, в добыче содержится также такая -порода, которая по действующим на шахте условиям засчитывается в чистую добычу. Сюда относятся мелкие куски породы размером менее 25 мм и известняковаячасть тех сростков, которые более чем наполовину состоят из сланца.

Содержание сланца в видимой породе и количество породы, включаемой в чистую добычу, на шахтах бассейна не определяется, что является причиной отсутствия полных и точных данных о размерах эксплуатационных потерь сланца. В настоящей работе приблизительное содержание пустой породы (известняка) в выдаваемом на поверхность рядовом сланце определено. расчетным путем на основании некоторых косвенных данных, полученных в период опытных работ.

Данные о содержании породы в рядовом сланце согласно расчетам и данные о видимой породе приводятся в таблице 2. 
Содержание породы в рядовом сланце при различных условиях породоотборки в забое (в процентах)

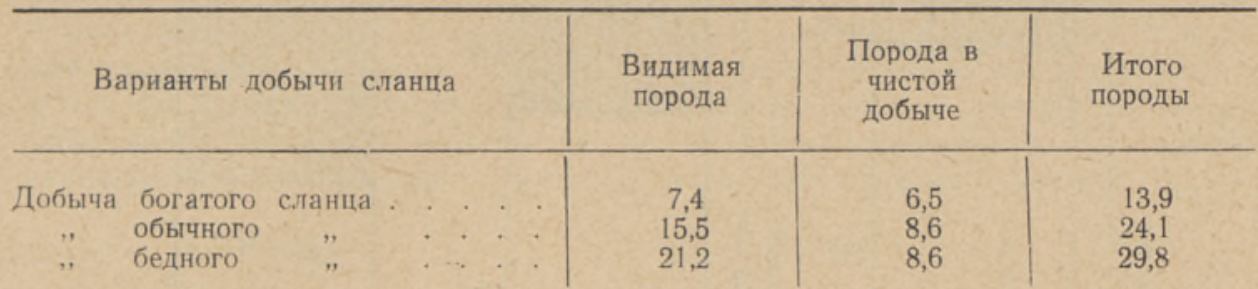

В соответствии с этими данными выход чистого сланца с квадратного метра площади выемки при добыче в обычных условиях породоотборки в забое равен

$$
\frac{2,12(100-24,1)}{100}=1,61 \mathrm{~T} / \mathrm{M}^{2} \text {. }
$$

Потери отбитого сланца в забое при этом варианте работ составляют

$$
\frac{(2,033-1,610) \cdot 100}{2,033}=20,8 \text { процента, }
$$

где 2,033 - полезная производительность разрабатываемого пласта.

Следовательно, при существующих условиях породоотборки, предусматривающих сортировку в забое мелких частиц горной массы и исключение из добычи сростков, содержащих менее 50 процентов сланца, безвозвратно теряется не менее пятой части отбитого сланца.

Добыча сланца при различных условиях породоотборки в забое позволила установить в период опытных работ характер и размеры влияния степени обогащения на уровень потерь сланца, а также на съем сланца с квадратного метра площади выемки.

Использование сланцевого пласта при добыче по всем трем вариантам опытных работ может быть охарактеризовано показателями, представленными в таблице 3 и на рис. 5 .

таблица 3

\begin{tabular}{|c|c|c|c|c|}
\hline \multirow[b]{2}{*}{ Показатели } & \multirow[b]{2}{*}{$\begin{array}{l}\text { Единица } \\
\text { измерения }\end{array}$} & \multicolumn{3}{|c|}{ Варианты добычи сланца } \\
\hline & & $\begin{array}{c}\text { Добыча } \\
\text { богатого } \\
\text { сланца }\end{array}$ & $\begin{array}{l}\text { Добыча } \\
\text { обычного } \\
\text { сланца }\end{array}$ & $\begin{array}{l}\text { Добыча } \\
\text { бедного } \\
\text { сланца }\end{array}$ \\
\hline $\begin{array}{l}\text { Полезная пронзводительность } \\
\text { пласта } \\
\text { Съем рядового сланца } \\
\text {," сланца без видимой породы } \\
\text { ", чнстого сланца } \\
\text { Потерганического вещества . } \\
\text { Потбитого сланша . }\end{array}$ & $\begin{array}{l}\mathrm{T} / \mathrm{M}^{2} \\
" \\
\dddot{\%} \\
\ddot{\%}\end{array}$ & $\begin{array}{l}2,033 \\
1,66 \\
1,54 \\
1,43 \\
0,563 \\
29,6\end{array}$ & $\begin{array}{l}2,033 \\
2,12 \\
1,79 \\
1,61 \\
0,633 \\
20,8\end{array}$ & $\begin{array}{l}2,033 \\
2,80 \\
2,21 \\
1,97 \\
0,768 \\
3,1\end{array}$ \\
\hline
\end{tabular}

Использование сланцевого пласта при различных условиях породоотборки

Таблица 3 и рис. 5 показывают, что условия минимальной породоотборки в забое представляют большие преимущества в отношении использования сланцевого пласта перед существующими условиями породоотборки и тем более в сравнении с глубокой породоотборкой. При минимальной породоотборке съем сланца (без видимой породы) увеличивается на 23,2 процента и органического вещества - на 21,2 процента. 


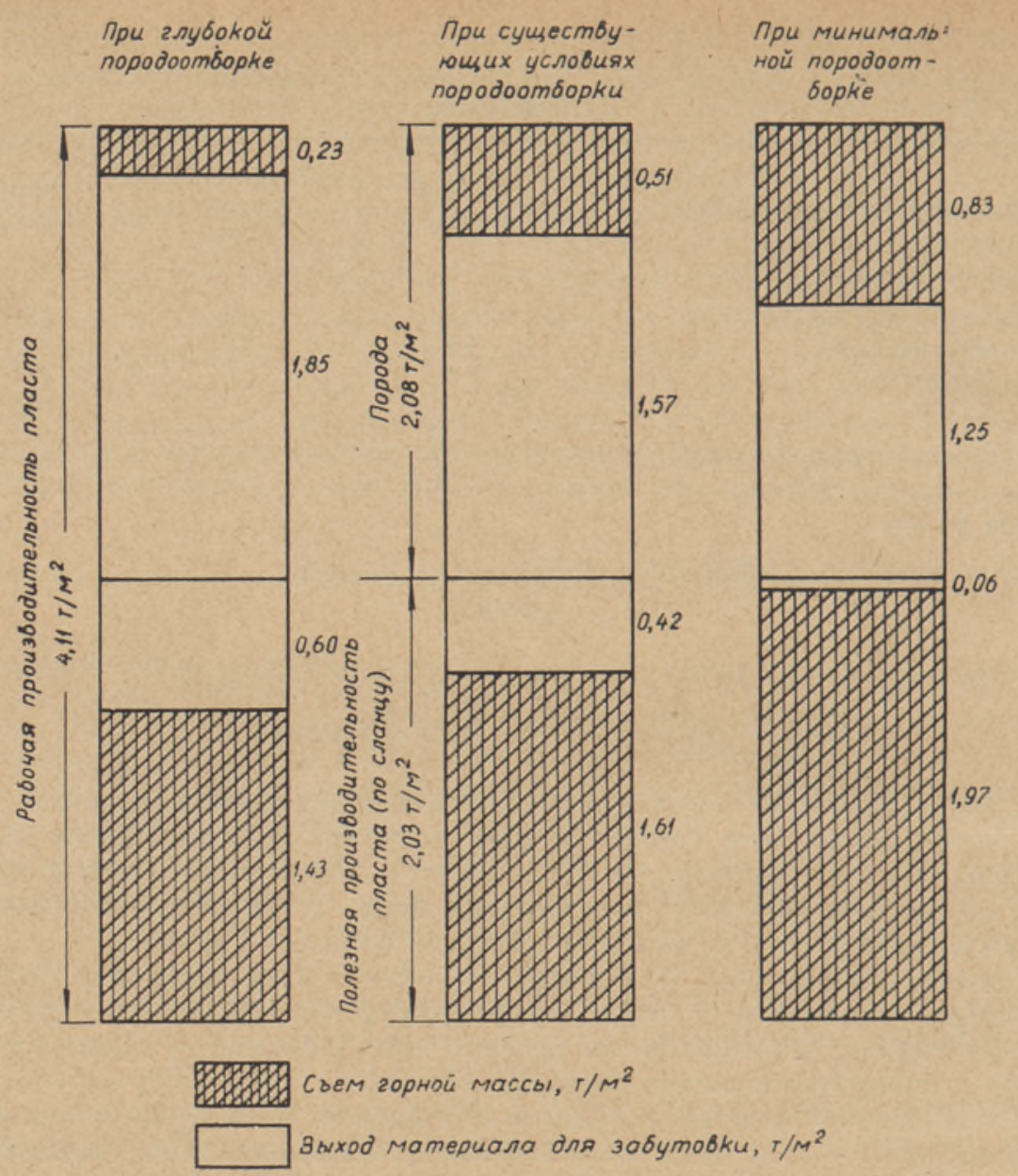

Рис. 5. Использование сланщевого пласта при различных условиях породоотборки в забое в период опытных работ в лаве № 19 шахты комбината жКивиыли», в июне 1954 г.

Это значит, что при достаточно производительном использовании оборудования лав и подземного транспорта производственная мощность и добыча шахты могут быть увеличены почти на $1 / 4$ без значительных капитальных затрат и прирезки новых шахтных полей.

Сравнение цифр съема сланца с квадратного метра площади выемки с производительностью пласта показывает, что добыча при минимальной породоотборке в забое обеспечивает извлечение почти всей массы сланца, заключенного в разрабатываемой части пласта. Потери сланца при этом составляют лишь 3,1 процента. По мере усложнения условий породоотборки в забое потери сланца растут: при обычных условиях породоотборки они составляют 20,8 процента, а при глубокой породоотборке 29,6 процента.

Зависимость потерь сланца и его съема с $1 \mathrm{~m}^{2}$ площади выемки от степени обогащения сланца под землей (рис. 6) такова, что по мере смягчения требований к породоотборке в забое и роста содержания видимой породы в добыче имеет место прогресси вное снижение потерь отбитого сланца и нарастание выхода сланца с 1 м $^{2}$ площади выемки. 
Но минимальная породоотборка в забое сопряжена с выдачей на поверхность дополнительного количества породы в ущерб потребностям в закладочном материале. Данные опытных работ, однако, показывают, что отказ от сортировки среди кусков горной массы крупностью до 75 мм и включение сростков в добычу не вносят коренных изменений в условия поддержания кровли. При выдаче бедного сланца в забое оставалось около 66 процентов горной массы, которая обычно используется для забутовки. Снижение количества закладочного материала происходит главным образом за счет сланца, т. е. за счет снижения потерь.

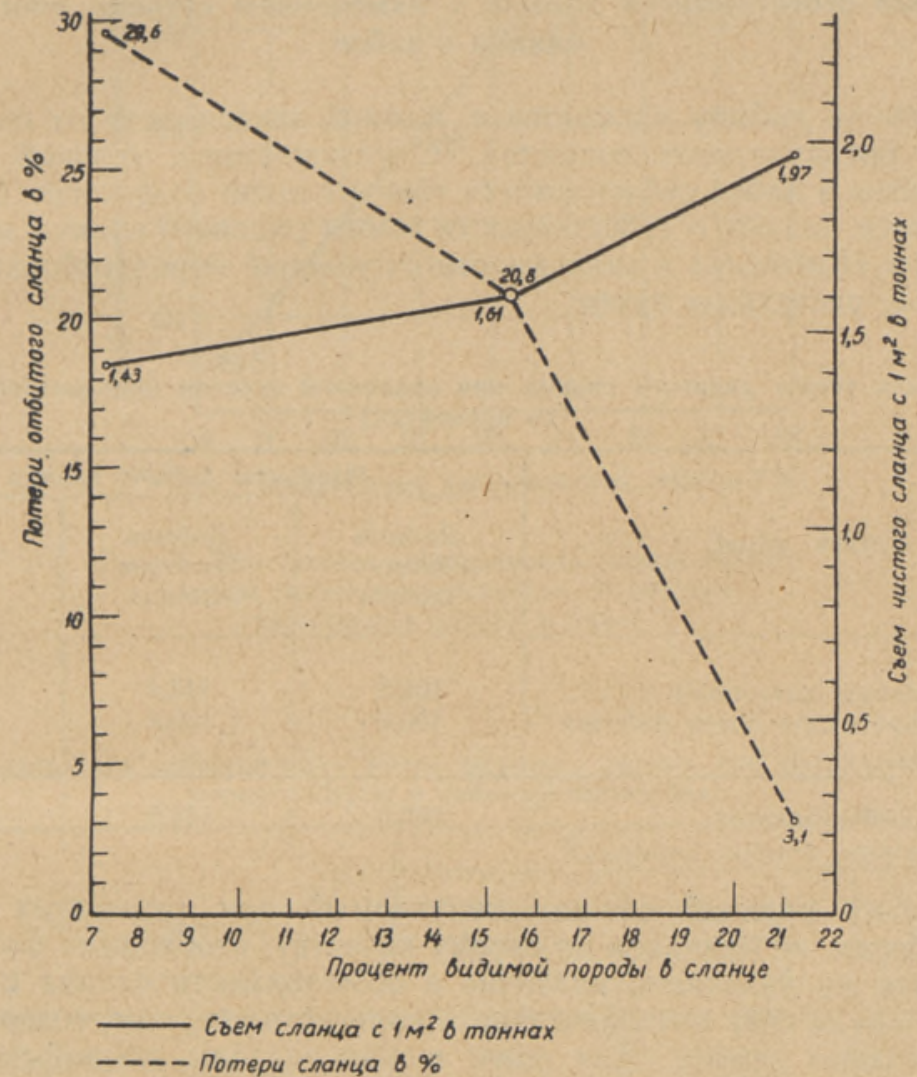

Рис. 6. Зависимость потерь отбитого сланца в недрах и его съема с 1 м² $^{2}$ площади выемки от степени породоотборки в забое.

Что касается породы, то количество ее, остающееся в лаве при выдаче бедного сланца, уменьшилось лишь на 20,5 процента. При этом снижение происходит в основном за счет мелких кусков породы, диаметром не более 75 мм, которые имеют наименьшую ценность в качестве бутового материала.

По данным Института геологии АН ЭССР, 66 процентов породы, содержащейся в отбитой горной массе, представляет собой крупные куски плиты размером более 125 мм. Эта часть породы, из которой прежде всего и выкладываются бутовые полосы, целиком остается в забое. Количество закладочного материала, остающегося в забое при минимальной породоотборке, составляет 32 процента от рабочей производительности пласта. 
В то же время нужно отметить, что выдача дополнительного количества породы на-гора при отказе от сортировки среди мелочи, не внося принципиальных изменений в условия поддержания кровли, все же не может не отразиться на них в той или иной мере. Поэтому обязательной предпосылкой уменьшения отбора породы в забое является разработка специального паспорта крепления или применение современных видов крепежных материалов для обеспечения полной безопасности работ в лаве.

\section{Снижение себестоимости добычи с изменением степени обогащения сланца в забое}

Затраты на добычу находятся в прямой зависимости от содержания в сланце органического вещества. С усложнением условий разборки горной массы в забое себестоимость тонны сланца возрастает. В таблице 4 приводятся данные о себестоимости тонны рядового сланца на участке № 2 шахты «Кивиыли» в зависимости от условий породоотборки в забое, полученные расчетным путем.

Таблица 4

Себестоимость тонны рядового сланца при различной степени породоотборки в забое (в процентах)

\begin{tabular}{|c|c|c|c|}
\hline \multirow[b]{2}{*}{ Статьи затрат } & \multicolumn{3}{|c|}{ Варианты добычи сланца } \\
\hline & $\begin{array}{l}\text { Добыча } \\
\text { обычного } \\
\text { сланца }\end{array}$ & $\begin{array}{l}\text { Добыча } \\
\text { богатого } \\
\text { сланца }\end{array}$ & $\begin{array}{l}\text { Добыча } \\
\text { бедного } \\
\text { сланца }\end{array}$ \\
\hline $\begin{array}{l}\text { Вспомогательные материалы } \\
\text { Основная заработная плата рабочих }\end{array}$ & $\begin{array}{l}100,0 \\
100,0\end{array}$ & $\begin{array}{l}146,4 \\
136,4\end{array}$ & $\begin{array}{l}77,0 \\
90,9\end{array}$ \\
\hline Участковая себестоимость & 100,0 & 144,0 & 80,5 \\
\hline
\end{tabular}

Поскольку рядовой сланец, получаемый при различных условиях породоотборки, не одинаков по своему качеству, необходимо рассмотреть, не является ли указанное различие в себестоимости сланца следствием роста добычи за счет дополнительного количества породы, содержащегося в более бедном сланце. Для этого нужно расходы по добыче отнести не ко всему количеству рядового сланца, а к его органической части. Участковая себестоимость тонны органического вещества при добыче богатого сланца на 26,2 процента выше, чем при добыче обычного сланца. При отказе от породоотборки среди мелочи и выдаче сростков добыча тонны органического вещества сланца по участку обходится на 12,8 процента дешевле, чем при добыче обычного сланца (рис, 7).

Тот же характер изменения удельных затрат в зависимости от условий породоотборки в забое обнаруживает фабрично-заводская себестоимость тонны рядового сланца.

Фабрично-заводская себестоимость тонны бедного сланца на 18,6 процента ниже, чем обычного. Добыча богатого сланца сопряжена с ростом себестоимости на 37 процентов.

Состав себестоимости (табл. 5) показывает, что ее снижение при добыче бедного сланца происходит за счет сокращения удельных затрат как живого, так и овеществленного труда. При этом значительнее всего снижаются наибольшие по удельному весу в себестоимости расходы заработной платы на тонну добычи и накладные затраты. 


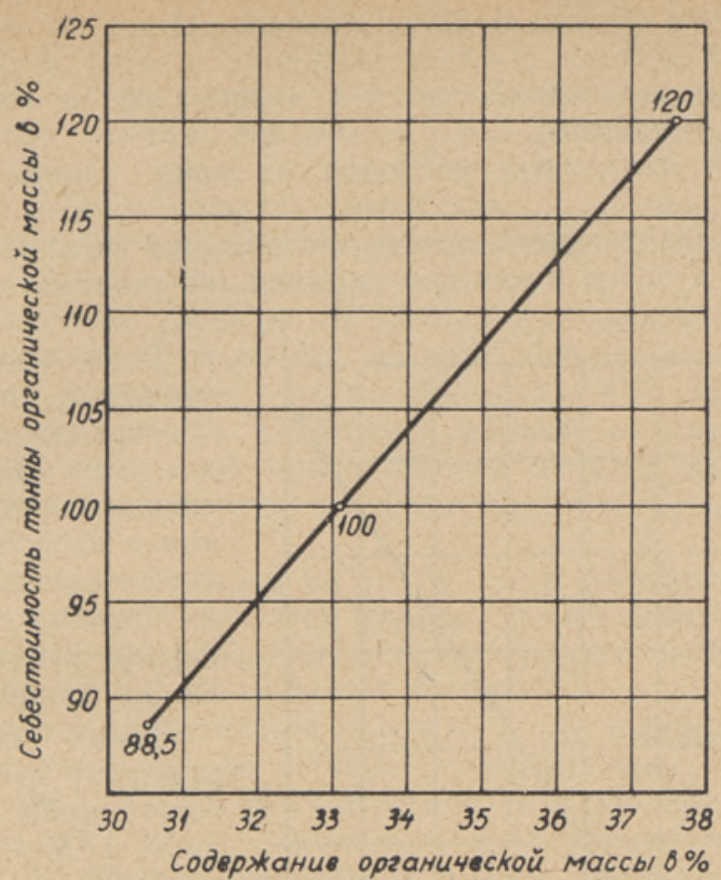

Рис. 7. Участковая себестоимость тонны органической массы в зависимости от степени обогащения сланца в забое.

Таблица 5

Фабрично-заводская себестоимость тонны рядового сланца при различных условиях породоотборки в забое (в процентах)

\begin{tabular}{l|c|c|c}
\hline \multirow{2}{*}{ Статьи затрат } & \multicolumn{2}{|c|}{ Варианты добычи сланца } \\
\cline { 2 - 4 } & $\begin{array}{r}\text { Добыча } \\
\text { обычного } \\
\text { сланца }\end{array}$ & $\begin{array}{c}\text { Добыча } \\
\text { сланца }\end{array}$ & $\begin{array}{c}\text { Добыча } \\
\text { бедного } \\
\text { сланца }\end{array}$ \\
\hline & 100,0 & 137,4 & 90,4 \\
Вспомогательные материалы & 100,0 & 11,5 & 89,2 \\
Электроэнергия & 100,0 & 146,7 & 79,4 \\
Заработная плата & 100,0 & 147,3 & 79,7 \\
Начисления & 100,0 & 121,7 & 82,2 \\
Цеховые расходы & 100,0 & 122,7 & 77,8 \\
Общезаводские расходы & 100,0 & 137,1 & 81,4 \\
\cline { 2 - 4 } & & &
\end{tabular}

Можно назвать следующие основные факторы снижения себестоимости добычи тонны бедного сланца в условиях минимальной для шахты «Кивиыли» породоотборки.

1. Снижение на тонну добычи затрат заработной платы рабочих забойной группы за счет роста производительности труда навалоотбойщиков и роста добычи.

2. Снижение удельных расходов крепежного леса на очистную добычу на 5 процентов, взрывчатых веществ на 9 процентов (хотя расход леса на весь цикл несколько увеличивается). 
3. Сокращение объема подготовительных работ по отношению к размерам очистной добычи (за счет снижения потерь) и связанная с этим экономия затрат заработной платы и материалов на прохождение подготовительных выработок.

4. Экономия накладных расходов на тонну сланца за счет роста добычи.

Выдача дополнительного количества видимой породы при упрощении породоотборки в забое несколько снижает получаемую при этом экономию.

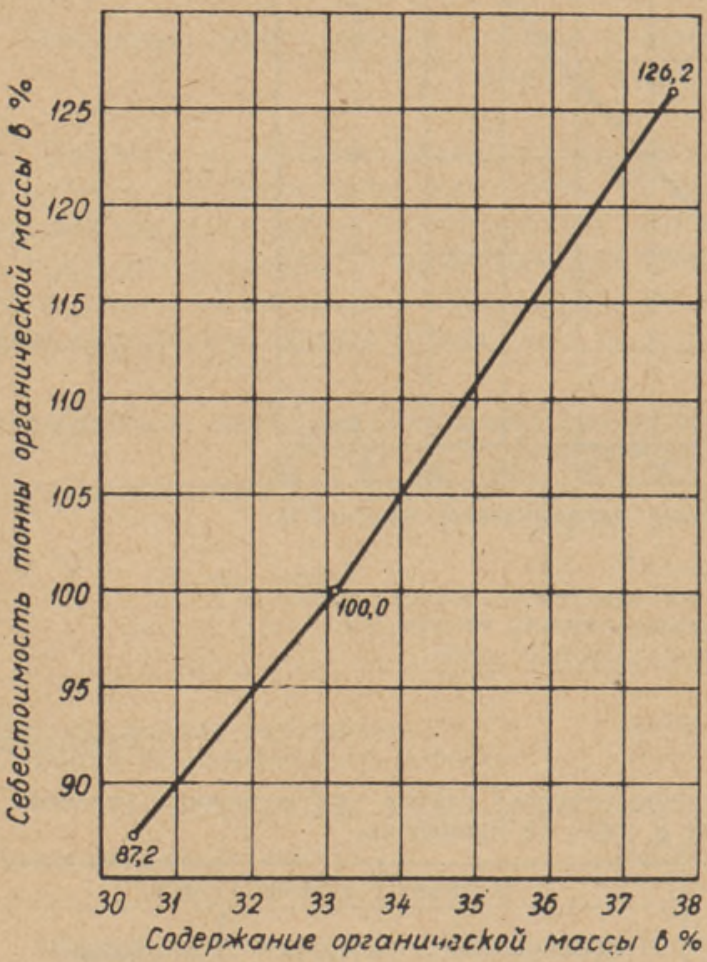

Рис. 8. Фабрично-заводская себестоимость тонны оғтанической массы при различной степени обогащения сланца в забое.

Если экономия за счет снижения потерь и увеличения производительности труда при добыче бедного сланца составляет в сравнении с себестоимостью обычного сланца 18,6 процента, то выдача дополнительной породы увеличивает затраты на 5,7 процента.

Таким образом, общее снижение себестоимости добычи тонны сланца составляет $18,6-5,7=12,9$ процента.

Фабрично-заводская себестоимость тонны органического вещества в бедном сланце на 11,5 процента ниже, а в богатом сланце на 20 процентов выше, чем в обычном (рис. 8).

Сравнение данных о себестоимости добычи сланца при различной степени породоотборки в забое свидетельствует о том, что добыча бедного сланща экономически более предпочтительна не только с точки зрения снижения потерь отбитого сланца и увеличения производительности труда, но и, как следствие этого, - с точки зрения экономии затрат на извлечение сланца из недр. Чтобы составить полное представление о размере этой экономии, следует выяснить, во что обходится добыча сланца равного качества, получаемого в одном случае обогащением его в забое и в другом - при выдаче бедного сланца и обогашении его на поверхности. Для целей этого расчета необходимо выделить из фабрично-заводской себестоимости сланца затраты на подземные работы, с тем чтобы расходы сортировочно-обогатительного цеха при последующих расчетах могли быть отнесены лишь на ту массу сланца, которая в существующих условиях подвергается дроблению, сортировке и обогащению в этом цехе.

Затраты на подземные работы из расчета на тонну богатого сланца на 38,1 процента выше, а бедного сланца на 12,5 процента ниже, чем на тонну обычного сланца. В последнем случае себестоимость в целях сравнимости определена по отношению к массе рядового сланца с таким же содержанием видимой породы, что и в обычно добываемом сланце. 


\section{Обогащение сланца на поверхности}

В настоящее время разработано несколько методов механизированного обогащения сланца, которые в промышленных условиях еще не испытаны.

Институтом «Ленгипрошахт» разработано проектное задание обогатительной фабрики шахта «Вивиконд» производительностью в 600 тыс. тонн рядового сланца в год.

Эксплуатационные расходы на обогащение одной тонны рядового сланца, доводящие содержание в нем органического вещества до 40-41 процента составляют в настоящее время 6,31 руб. Это все еще довольно высокие расходы. Поэтому в данный момент имеет значение исследование экономической эффективности ручного обогащения сланца на поверхности, на смену которому в последующем придет механическое обогащение.

Ручное обогащение сланца на поверхности обеспечивает повышение качества сланца до необходимого уровня. Это объясняется тем, что, как показали исследования, отказ от породоотборки в забое среди кусков величиной менее 75 мм не вызывает значительного ухудшения качества сланца в отношении содержания в нем видимой породы и органической массы. Доля видимой породы в сланце, увеличившись во время проведения опытных работ на 5,7 процента (до 21,4 процента), не вышла за пределы колебаний этого показателя в обычных производственных условиях. Так, в течение сентября в добыче лавы № 20 содержание видимой породы в отдельные дни составляло 21,8-23 процента; в добыче лавы № 23 - 19,5 процента. Такие цифры, правда, редки и означают нарушение бригадами навалоотбойщиков требований к качеству продукции, однако они показывают, что условия данного варианта испытаний не являются принципиально новыми и не сопряжены с коренными изменениями как в характере горных работ, так и в качестве сланца.

Действительно, в период опытных работ содержание органической массы в рядовом сланце уменьшилось не более чем на 2,7 процента (33,1 - 32,6 процента в обычном и 30,4 процента в бедном сланце).

Эти цифры относятся к рядовому сланцу, в то время как обогащению подвергается обычно технологический сланец, представляющий собой остаток рядового сланца после отделения от него мелочи, а иногда и первого сорта с размером кусков более 125 мм.

С целью сравнения показателей рядовой сланец расчетным путем приводится к технологическому.

Таблица 6

Содержание условной органической массы в сланце (на сухое вещество) при различных условиях породоотборки в период опытных работ на шахте жКивиыли» (в процентах)

Добыча обычного сланца

а) в период с 7 по 9 VI $1954 \mathrm{r}$.

б) в пернод с 24 по 28 IX 1954 r.

Добыча богатого сланца (10 и 11 VI 1954 r.)

Добыча бедного сланца (с 14 по 19 V1 1954 г.)

\begin{tabular}{|c|c|c|c|}
\hline \multirow{3}{*}{$\begin{array}{l}\text { В рядовом } \\
\text { сланце }\end{array}$} & \multicolumn{3}{|c|}{ В технологическом сланце } \\
\hline & \multicolumn{2}{|c|}{$\begin{array}{c}\text { До обогащения на } \\
\text { поверхности }\end{array}$} & \multirow{2}{*}{$\begin{array}{c}\text { После обога- } \\
\text { щения на по- } \\
\text { верхности }\end{array}$} \\
\hline & $\begin{array}{l}\text { после отде- } \\
\text { ления I сорта }\end{array}$ & $\begin{array}{l}\text { без отделе- } \\
\text { ния I сорта }\end{array}$ & \\
\hline $\begin{array}{l}33,1 \\
32,6\end{array}$ & $\begin{array}{l}30,7 \\
30,0\end{array}$ & $\begin{array}{l}32,7 \\
32,0\end{array}$ & $\begin{array}{l}\text { не определя- } \\
\text { лось } \\
37,2\end{array}$ \\
\hline 37,6 & 38,2 & 38,8 & лось \\
\hline 30,4 & 26,5 & 29,2 & 33,4 \\
\hline
\end{tabular}


Во второй и пятой графах таблицы 6 приведены непосредственно определенные данные, в третьей и четвертой - расчетные. В третьей графе таблицы показано содержание органической массы в технологическом сланце, остающемся после отсортировки мелочи и первого сорта. В эксплуатационных условиях на переработку направляется .именно такой сланец. Поэтому для сравнения цифр содержания органического вещества в сланце, полученном в период опытных работ, с соответствующими эксплуатационными показателями берутся данные из третьей графы: $30-30,7$ процента для обычного и 26,5 процента для бедного сланца.

Цифры четвертой графы характеризуют выданную на поверхность горную массу за вычетом одного лишь отсева, т. е. тот сланец, который во время опытных работ подвергался обогащению на поверхности.

В результате обогащения обычного технологического сланца содержание органического вещества в сланце повысилось с 32 до 37,2 процента, т. е. на 5,2 процента. В сланце, добытом в условиях минимальной породоотборки в забое, содержание органического вещества увеличилось с 29,2 до 33,4 процента, т. е. на 4,2 процента. Тем самым на поверхности был получен сланец, превосходящий по качеству обычно добываемый сланец, который после отделения сланцевой мелочи содержит 32,0 - 32,7 процента органической массы (табл. 6).

Отборка породы на поверхности осуществлялась в сортировочнообогатительном цехе комбината «Кивиыли», оборудованном движущимися металлическими лентами, в галереях, специально приспособленных для работы выборщиков породы.

Обогащению подвергался технологический сланец (фракция $25-$ 100 мм), полученный путем дробления рядового сланца в специальной дробилке и отделения сланцевой мелочи (фракция $0-25$ мм).

При обогащении бедного сланца выборщики породы отделяли за смену 40 т породы (или 11 процентов от всего рядового сланща). Следовательно, для повышения содержания органического вещества в сланце на один процент потребовалось отделить от каждых 100 т рядового сланца 2,5 т породы. При обогащении обычного сланца этот показатель равнялся 2 т на 100 т рядового сланца.

Производительность труда выборщика породы при обогащении бедного сланца до обычного равнялась 2,85 т и при обогащении обычного сланца до богатого - 3,15 т породы за смену. На отделение 1 т породы бригаде требовалось в среднем 2,3 человеко-часа (включая простои). Таким образом, для повышения содержания органического вешества в 100 т рядового сланца на один процент было затрачено 4,5-5,5 человеко-часа. Если исходить из того, что коэффициент использования рабочего дня выборшика породы будет не $53,5 \%$, как это имело место во время опытных работ, а по меньшей мере 75 , то на отделение 1 т породы от рядового сланца потребовалось бы 1,9 человеко-часа и на повышение содержания органического вещества в 100 т рядового сланца на один процент 4-4,5 человеко-часа.

Добыча бедного сланца и его обогащение на поверхности дают уменьшение трудоемкости работ по добыче I т сланца по всей шахте на 14,5 процента, Указанный экономический эффект следует считать минимальным, так как при лучшей организации работ он мог бы быть значительно бо́льшим.

В связи с обогащением сланца неизбежно возникают его потери. В отбираемую породу попадает сланец как в чистых кусках, так и в сростках с известняком. Обогащение технологического сланца на поверхности заметно отличается от обогащения, проводимого навало- 
отбойщиком в лаве. Выборщики породы на поверхности, находясь в лучших условиях, добиваются более высокой производительности труда и значительного сокращения потерь отбитого сланца.

Потери сланца при обогащении бедного сланца до обычного уровня составили 1,7 процента и при обогащении обычного сланца до содержания органического вещества в 37,2 процента- были равны 1,45 процента. При добыче бедного сланца и его последующем обогащении до обычного уровня на поверхности общие потери (потери в лаве и при обогащении на поверхности) равны 4,8 процента, что в 4 раза меньше потерь при подземном обогащении сланца до обычного уровня. При обогащении бедного сланца на поверхности потери сланца будут в 7 раз меньше, чем при добыче богатого сланца.

\section{Cебестоимость сланиа обычного качесmbа ( 8 \%)}

$\begin{array}{cc}\text { При обога- } & \text { При обога- } \\ \text { щении в за- } & \text { щении на } \\ \text { бое до 32,7\% } & \text { поверхности } \\ \text { орг. веци. } & \text { с } 29,2 \% \text { до } \\ & 33,4 \% \text { орг } \\ & \text { вещ.. }\end{array}$

100,0

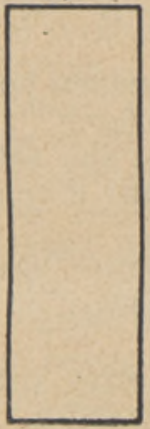

92,2

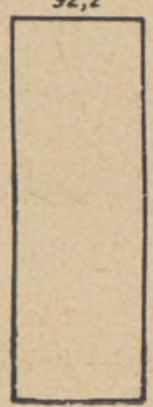

Ceбecmoumocmb "богаmoro" сланиа ( $8 \%)$

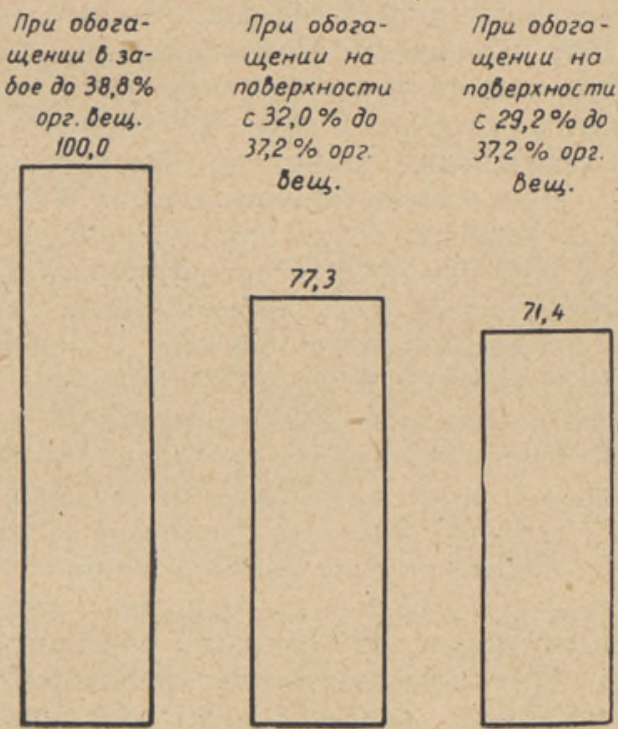

Рис. 9. Себестоимость 1 тонны технологического сланща при различных варнантах его ручного обогащения.

Расходы по обогащению одной тонны бедного сланца до обычного уровня составляют 1.13 руб,, а по обогашению того же количества обычного сланца до наивысшего уровня - 1.03 руб. Повышение содержания органического вещества в сланце в среднем на один процент (в пределах $30-38$ процентов) обходится в 20-24 коп.

Себестоимость бедного сланца, обогащенного на поверхности до обычного уровня, значительно ниже себестоимости обычного сланца при подземной породоотборке. При обогащении на поверхности сланец одного и того же качества обходится на 7,8 процента дешевле, чем при подземном обогащении (рис. 9).

Совершенно неэкономичной является добыча богатого сланца, требующая от шахтеров породоотборки в лавах до содержания в сланце органического вещества в 37-38 процентов. В сравнении с себестоимостью такого сланца затраты на добычу тонны обычного сланца и на его последующее обогашение до уровня богатого сланца оказываются на 22,7 пропента ниже. Наиболее выгодно добывать бедный сланец и обогащать его 
на поверхности. В этом случае себестоимость сланца на 28,6 процента ниже себестоимости добычи сланца такого же качества, но обогащенного в лаве (рис. 9).

\section{Выводы}

1. Уровень потерь отбитого сланца находится в прямой зависимости от условий породоотборки в забое. При существующих требованиях к породоотборке под землей потери отбитого сланца составляют пятую часть возможного выхода сланца и четвертую часть фактического выхода. Отказ от породоотборки среди мелких фракций (куски менее 75 мм) позволяет свести потери сланца к минимуму, увеличить съем рядового сланца (без видимой породы) с квадратного метра площади выемки на 23,2 процента и съем органического вещества - на 21,2 процента. При этом качество сланца в отношении содержания в нем органического вещества и видимой породы понижается незначительно. Закладочного материала остается в забое в количестве, достаточным для выкладки бутовых полос.

При обогашении бедного сланца до обычного уровня на поверхности потери сланца увеличиваются всего лишь на 1,7 процента и составляют вместе с потерями в забое 4,8 процента, что в четыре раза меньше потерь при обогащении сланца до обычного уровня в забое.

2. При добыче бедного сланца в сравнении с добычей обычного производительность труда навалоотбойщиков повышается по рядовому сланцу на 43,5 процента и по органическому веществу на 32 процента. Снижается трудоемкость добычи тонны сланща. На добычу тонны обычного сланца затрачивается 36,5 мин., а бедного - 25,5 мин.

Рост производительности труда обусловлен также уменьшением потерь отбитого сланца и соответствующим увеличением объема добычи.

Производительность труда одного рабочего по всей шахте при добыче бедного сланца и обогащении его на поверхности повышается в сравнении с добычей обычного сланца на 17 процентов,

3. Себестоимость добычи тонны бедного сланца с учетом затрат, связанных с выдачей на-гора дополнительного количества породы, на 12,9 процента ниже себестоимости обычного сланца.

4. Для удовлетворения требований потребителей к качеству сланца экономически целесообразно обогащение сланца на поверхности. При добыче бедного сланца и обогащении его до обычного уровня расходы по обогащению 1 т сланца вручную на транспортерной ленте составляют 1 руб. 13 коп., а при обогащении до содержания органического вещества в 37,2 процента - 2 руб. 16 коп.

Еще больший экономический эффект может быть получен с переходом к механическому обогащению.

5. Переход на добычу бедного сланца с последующим его обогащением на поверхности только до обычного уровня в сравнении с обогащением такого же сланца в забое даст экономию по щахте «Кивиыли» в сумме 2,6-2,7 млн. руб. в год.

6. Добыча бедного сланца и его обогащение на, поверхности имеют значение и для шахт треста «Эстонсланец».

Таким образом, отказ на шахтах сланцевого бассейна от тщательной породоотборки в забое и переход на добычу бедного сланца с последующим его обогащением на поверхности позволит сберечь для государства большое количество безвозвратно теряемого в настоящее время сланща, повысить производительность труда шахтеров и даст значительную экономию средств. 